\title{
Livingstone versus Serota: the High-rise Battle of Bankside
}

\author{
ANDREW HARRIS \\ University College London, UK
}

In 2001, plans were unveiled by a private developer for a 32-storey residential tower next to the Tate Gallery of Modern Art in Bankside. Although not the tallest building proposed within London's high-rise landscape, this tower became a minor cause célèbre within the city's media. The twists and turns involved in attempts to win - and oppose - planning permission for the building are charted in this paper. Yet, the vociferous battle involved does not reveal distinct political and social fault-lines. Instead, it highlights how an agenda of corporate property-led development has come to dominate efforts to regenerate and re-imagine contemporary London.

\section{Introduction}

Over the last decade, tall buildings have become an increasingly prominent feature not just on London's landscape but within its written media. Newspapers have provided eager coverage, not only as part of a wealth of new property supplements catering to London's ever escalating property boom, but as part of a latest bout of wrangling between London's pro-tall buildings mayor, Ken Livingstone, and heritage enthusiasts. Several books have been published feeding and responding to greater popular interest in urban history and architecture, itself often mined in the branding and design of new tall buildings. ${ }^{\mathrm{T}}$ No less significant has been a flurry of features in the property press, revelling in the firmly established new high-finance role for London's former docks, dubbed 'Manhattan-by-Thames', and the metamorphosis since the I970s of residential high-rises from modernist eyesores to highly desirable apartments.

As well as charting the design details, market prices and commercial tenants of London's new tall buildings, this coverage has been as much about what has yet to be built - or what could be built - as what has already been constructed. It has highlighted not only a new landscape of steel, mirrored glass and cranes, but also a whole nervous system of proposals, publicity and rumours surrounding building high in London. It is from this more speculative world of financial projections, media strategies and planning battles that the concrete constructions dotting London's skyline emerge. Yet, studies of tall buildings have tended to neglect how particular 
aesthetic discourses are marshalled and new strategic alliances fermented prior to building. As the ongoing controversy over New York's Freedom Tower indicates, the power games and symbolic struggles behind buildings still on the drawing-board can reveal just as much about the wider dynamics of a city as successfully completed structures. ${ }^{2}$

The focus of this paper is on a tall building in London that has received widespread media coverage since $200 \mathrm{I}^{3}$ - yet has not been constructed (Figure I). At 20 storeys (in its successful planning application) and occupying a I,035 square metre site, it is not one of the tallest or largest buildings proposed within London's new vertical landscape. Nor is it one of the most iconic or architecturally significant; unlike other proposed tall buildings in London, it has not received a media sobriquet such as 'cheese grater' or 'walkie-talkie' connected to a distinctive design. ${ }^{4}$ It has, nevertheless, been identified by its location. Situated at 44-47 Hopton Street, 50 metres from the Turbine Hall entrance to the Tate Gallery of Modern Art at Bankside, it has been referred to as the 'Tate Tower'.

Drawing on newspaper articles, planning documents and interviews, this paper will outline how plans for this site brought into opposition two coalitions of high profile actors. On one side, the proposed tower's developers and architects were supported by Ken Livingstone. On the other, plans were vehemently contested by a group of well-organised residents and the Tate. Yet, the paper will argue that these two seemingly opposing sides actually share a similar political and economic agenda. Although undeveloped, the Hopton Street site not only illustrates some significant planning

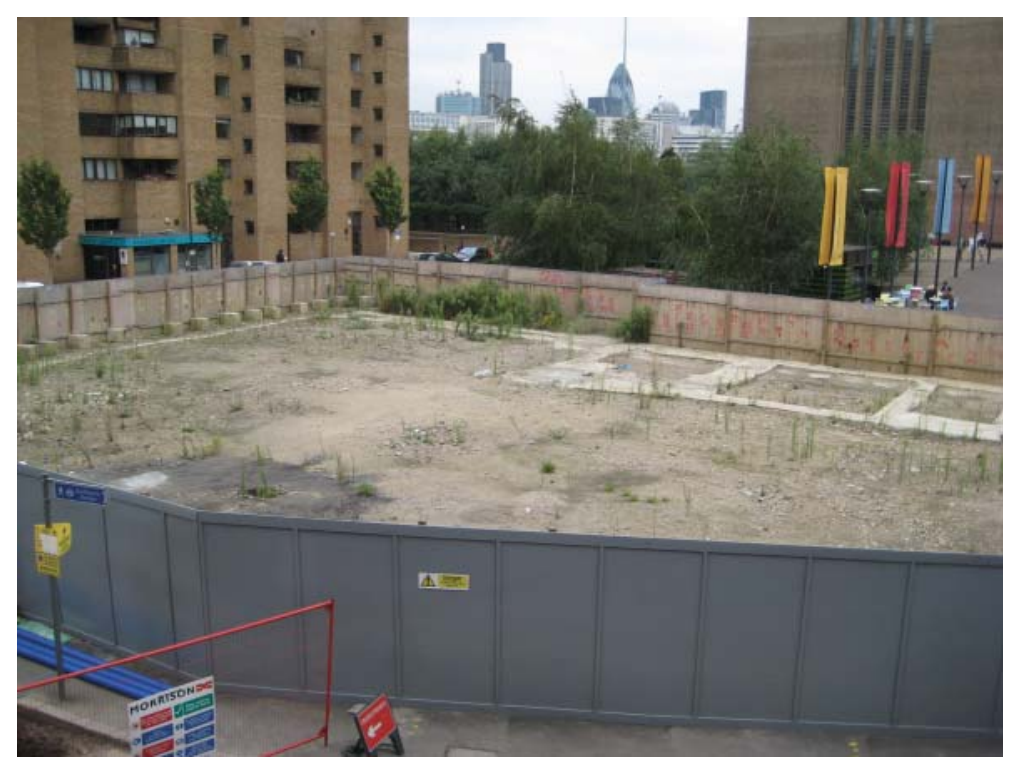

FIGURE 1 The empty site at 44-47 Hopton Street, September 2007. The western flank of Tate Modern can be seen at the top right of the photograph, the residential Falcon Point building is top left. The photograph was taken by the author from the second floor of Bankside Lofts 
issues and debates within contemporary London, but highlights important contradictions and compromises inherent in recent attempts at urban regeneration through high-rise building.

\section{High-rise battle lines in millennial Bankside}

Until 2004, when it was demolished, the site at 44-47 Hopton Street contained a twostorey building, complete with small brick chimney, one of the few remaining traces of Bankside's Victorian industrial legacy. Built in I867 as a stables and wheelwrights, this building was part of a jumble of gas works, metal foundries, large wharves and food processing industries that emerged in the area during the late nineteenth century. ${ }^{6}$ War damage and speculative office development from the I970s onwards meant that by the I990s much of this original industrial fabric had disappeared. The Tate Gallery's I994 purchase and subsequent refurbishment of a large redundant brick power station, built between I948 and I963 complete with a 99 metre chimney, firmly signalled a new postindustrial role for the area. The Hopton Street building, however, owned by paper merchants, remained operational during the I990s as a warehouse and wholesale distribution centre.

In December 2000 , the building was sold for $£_{7.6}$ million to London Town plc. The building was not listed and London Town acquired the site anticipating that planning consent for a new glass-fronted residential tower would be secured within I8 to 24 months. London Town had already successfully managed the redevelopment of a former Shell riverside storage depot near Wandsworth Park, and were keen to tap further into a growing market for upmarket riverside flats. ${ }^{7}$ Within walking distance of the City of London over the newly opened Millennium Bridge, and with views of St Paul's Cathedral, the proposed tower was well placed to cater to demand from high-income professionals for centrally-located luxury flats. Moreover, with Southwark Council supporting a proposal to build a $305 \mathrm{~m}$ mixed-use tower in nearby London Bridge, it appeared planners were increasingly receptive to developing a cluster of tall buildings on the Southwark side of the Thames.

The proposed tower at Hopton Street also chimed with an enthusiastic backing of tall buildings by Ken Livingstone, who had become the city's first democratically elected Mayor eight months before London Town purchased the site. Livingstone's pro-tall building agenda was founded on a series of interconnected calculations. ${ }^{8}$ First, he saw London's skyline as an important means of asserting and consolidating London's 'global city' status, both in terms of meeting demand for office space and architectural innovation. Second, in the context of limited financial autonomy invested in the new Mayor by the Blair government, backing tall buildings was a way of helping secure progressive forms of planning gain from developers. Third, Livingstone viewed tall buildings as an important part of efforts to make London a more sustainable city in the face of growing pressures for new offices and housing. ${ }^{9}$

In June 200I, Livingstone met London Town and urged them to increase the proposed building from 29 storeys to 32 (Figure 2). By building to I I $\mathrm{m}$, the developers would be able to raise the proportion of affordable homes from 35 to 50 per cent, meeting Livingstone's target for new housing schemes. ${ }^{\text {Iо }}$ Building taller also allowed London Town to claim that the proposed tower would increase inner-city housing 


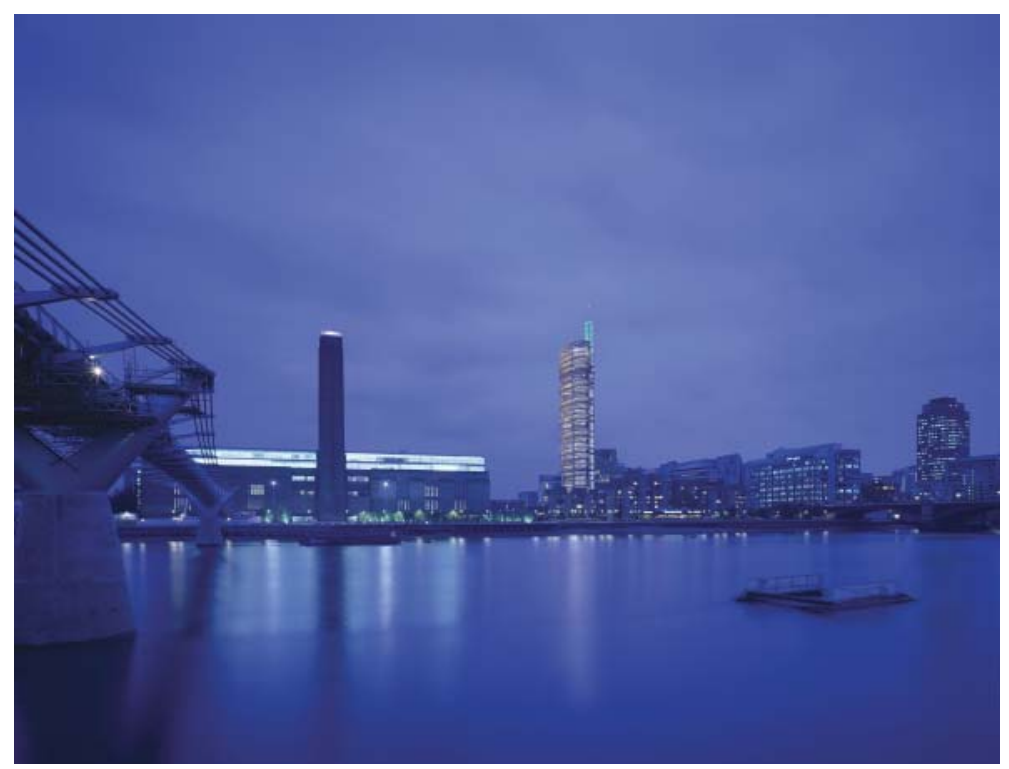

FIGURE 2 The proposed 32-storey tower at Hopton Street, as viewed from the North Bank of the Thames opposite the Tate Modern building. Reproduced by kind permission of Kevin Dash Architects and Gumuchdjian Architects. Image by Hayes Davidson

density. This emphasis on city centre living as an essential objective of sustainable planning reflected the interests of the tower's co-architect, Philip Gumuchdjian, a former colleague of Richard Rogers who helped write the influential book, Cities for a Small Planet (I997).

Winning support from Livingstone, London Town's proposals for a 32 -storey tower seemed well set to secure planning consent. The developers, nevertheless, did not anticipate the levels and scope of resistance to the tower. In particular, residents from buildings directly adjacent vehemently objected to London Town's plans, and a group called Bankside Residents Against the Tate Tower (BRATT) was formed. They staged a mock wake outside the site in September 200I, cutting a cake shaped like a coffin to mark the demise of the old building. ${ }^{\text {II }}$ Their objections were four-fold. Firstly, they argued that the proposed tower would hem in existing buildings and dramatically reduce light. They also were greatly concerned about their privacy. As one resident stated in a letter to Southwark Council, 'I will become an exhibit in my own home, unless I live permanently with the blinds and curtains closed'. ${ }^{\text {2 }}$ Thirdly, objections were mobilised around the impact the new tower would have on the 'townscape' of Bankside. Lastly, the proposed building was viewed as detrimental to Tate Modern, blocking its Western entrance and 'cashing in' on the public benefits it had brought to the area.

This last complaint stemmed from vociferous objections raised by Sir Nicolas Serota, Director of the Tate. Awarded $£_{5} 0$ million from the National Lottery, as well as over $£_{\mathrm{I} .5}$ million from Southwark Council, the Tate had provided Bankside with a new internationally recognisable profile and amenity. ${ }^{\mathrm{I} 3}$ For Serota, London Town's 
purchase of the Hopton Street site only six months after Tate Modern had opened was 'an opportunistic attempt to cash in for private gain on the public benefits' that had been created. Furthermore, with the proposed building 28 metres taller than the former power station's chimney - ceremoniously topped by a new light beacon the tower was seen as a direct affront to the Tate. As Serota forcibly argued in September 200I, perhaps reflecting on the Tate's failure to buy the Hopton Street site in I996, it was the equivalent of building 'a tower block in the forecourt of the British Museum'. He suggested the tower's presence within $50 \mathrm{~m}$ of the Tate's Western entrance and the ramp down into the Turbine Hall would 'inevitably diminish the quality and value of the public space for millions of visitors', dismissing the inclusion of affordable housing in the plans as a 'cynical move'. ${ }^{\mathrm{I}}{ }^{2}$ The Tate's trustees subsequently lodged a formal objection to the planning application.

Complaints against the tower mounted by residents and amplified by Nicolas Serota were sympathetically received by a number of influential voices beyond Bankside. The controversy was picked up by metropolitan and national newspapers, especially in the context of Prince Charles's pronouncements in December 200I that new tall buildings in London were 'overblown phallic structures' that ruined the skyline of the capital. ${ }^{15}$ Opponents of the Hopton Street tower, however, found it less easy to bring English Heritage on board. In August 200I, their historic areas' adviser in London, announced that 'we have not yet decided on our position on this', commenting how the tower was unlikely to affect the view of Southwark Cathedral or to or from St Paul's. ${ }^{\text {I6 }}$

\section{Planning battles: the 'ups' and 'downs' of developing the Hopton Street Tower}

With their plans set against this intense lobbying not only from nearby residents but from influential actors such as Sir Nicolas Serota, London Town were forced to retreat. Realising Southwark planners were unlikely to accept their proposal, London Town withdrew their application in December 200I. They sought, however, to reach a compromise. They submitted a new design to Southwark in June 2002, which was I2 storeys and 56 metres shorter (Figure 3). This 20-storey building, 36 metres lower than the Tate's 'chimney', was given tacit support by Southwark's planning officer and English Heritage. Yet with seven of the proposed 28 apartments designated as 'affordable' — only 25 per cent - Ken Livingstone was less enthusiastic. Following threats to direct Southwark to refuse planning permission unless a greater percentage of affordable housing was included, the developers raised the number of affordable units to nine, 35 per cent of the scheme. Nevertheless, in October 2002, the application was rejected by Southwark's Planning Committee by seven votes to one. Having received $\mathrm{I}_{44}$ letters of objection and only one letter of support, Southwark councillors (from all three main political parties) refused it on the grounds of a loss of amenity and privacy for local residents, and over concerns the tower would have an adverse aesthetic impact on surrounding buildings, including Tate Modern. ${ }^{\mathrm{I} 7}$

London Town, arguing their application had been turned down for 'emotional' rather than judicial reasons, subsequently lodged an appeal against Southwark's decision and a full planning inquiry was set for May 2003 before an inspector 


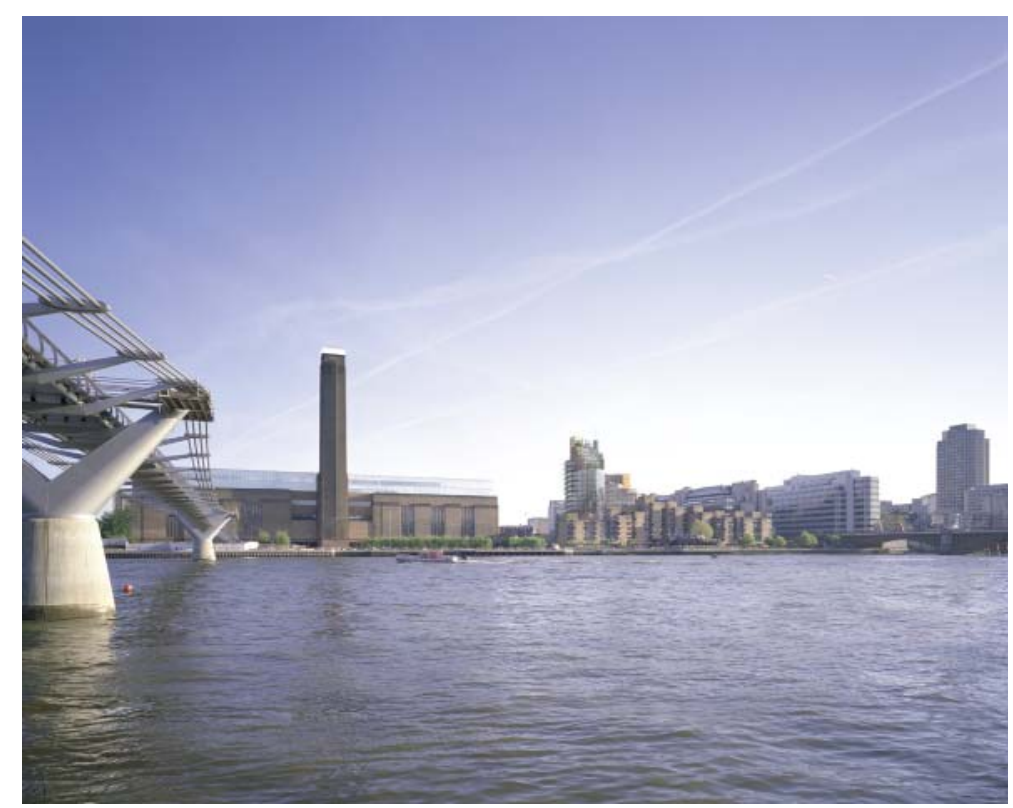

FIGURE 3 The proposed 20-storey tower at Hopton Street, as viewed from the North Bank of the Thames opposite the Tate Modern building. Reproduced by kind permission of Kevin Dash Architects and Gumuchdjian Architects. Image by Hayes Davidson.

appointed by John Prescott, Deputy Prime Minister. BROAD (Bankside Residents for Appropriate Development) — the new name for BRATT — responded by recruiting Mishcon de Reya, the former law firm of Diana, Princess of Wales, to coordinate the case against the tower. The Tate similarly commissioned Professor Jan Gehl, a Danish expert in urban design, to produce a public space plan. Yet, praising how the building's 'elegant design' would provide a 'meritorious counterpoint to the mediocre surroundings of the site', the planning inspector decided to reverse Southwark council's refusal of the scheme and planning permission was granted. ${ }^{18}$

The inspector's decision would usually be final. However, several strategies were devised in response to sustain the battle against the tower being built. First, the Tate threatened to build a galvanised metal wall to cut the tower off from the Tate's western entrance. Co-architect Kevin Dash condemned this proposal, calling it a 'stupid and spiteful thing to do, particularly in a public open space which has had $£ 250$ million of public funding'. ${ }^{\prime 9}$ Second, BROAD launched a series of unusual legal appeals challenging the inspector's decision, benefiting from being able to draw on resources and legal expertise necessary to continue their opposition. ${ }^{20}$ BROAD firstly secured a judicial review in the High Court in December 2003. Richard Clayton QC argued that their right to the enjoyment of their property under the European Convention on Human Rights would be breached if the tower was built. But in January 2004, the judge rejected the appeal, concluding how 'in an urban setting, high-rise buildings are inevitable, having regard to building costs and the value of city centre land'. ${ }^{21}$ Undeterred, BROAD took their case to the Court of Appeal in June 
2004, but three appeal judges again backed the inspector's decision. Subsequently, they petitioned the House of Lords for leave to appeal, but in November 2004 this was dismissed. Finally, BROAD took their case to the European Court of Human Rights in Strasbourg. The chair of the group, David Lough, explained this highly unusual move: 'the rights of residents are not sufficiently considered in the existing UK planning process and we think the law needs to be challenged'. ${ }^{22}$

With the proposed tower still stuck in limbo, London Town ran short of money by the end of 2004 and were forced to issue new shares. Indeed, BROAD were aware that the developers, without comparable resources to major property conglomerates, had become increasingly financially insecure. ${ }^{23}$ In January 2005 , London Town sold the Hopton Street site — complete with planning permission — for $£_{\text {IO. }} 8$ million to Meyer Bergman, a large Dutch developer. Following BROAD’s European appeal failing, preparatory work finally started on the tower in March 2006. Yet three months later work stopped. This was in response to GC Bankside, a joint venture between Clan Real Estate and Grosvenor, submitting a planning application for the demolition of the existing buildings at Bankside Industrial Estate, just to the south of the Hopton Street site, and the development of a scheme designed by Richard Rogers comprising 229 residential units in five buildings up to 24 storeys. As part of this proposal, GC Bankside had reached an agreement with Meyer Bergman to purchase the Hopton Street site subject to planning permission. If this was granted, GC Bankside proposed to abandon the construction of the Hopton Street tower and dedicate the land 'for open space, with a possible pavilion type structure for community, cultural and/or recreational uses'. ${ }^{24}$

For the Tate, this was a 'considerably preferred approach' while BROAD approved of their proposal to concentrate development to the south and 'leave the northern, 44 Hopton Street site as a public site'. ${ }^{25}$ Ken Livingstone, although commending 'the high quality of the design' did 'not accept the low level of affordable housing provision'. This, according to GC Bankside, was due to the 'exceptional circumstances' and 'high costs' of acquiring the Hopton Street site. Yet GC Bankside's rationale for incorporating this site into their overall plan remained unclear. A Greater London Authority report suggested:

The decision to purchase the Hopton Tower site appears to have been based on a desire to minimise local opposition by providing a guarantee to residents that the Hopton Street Tower scheme, which was the subject of significant local opposition, is no longer implemented. ${ }^{26}$

GC Bankside's purchase of the Hopton Street site and their advocacy of its use as a public space may have been an attempt to reduce their affordable housing commitments, but it seems it has also been a canny strategy to win over local support. By finally quelling the bitter battle over $44-47$ Hopton Street, Bankside's 'regeneration' could continue apace.

\section{The politics of verticality in postindustrial London}

Debates over the Hopton Street tower between 2000 and 2006, have differed from many similar planning controversies in central London. Although arguments were made against the tower's potential impact on views and sightlines along the river 
and towards St Paul's Cathedral, they were largely not couched around a cherished historic ideal of the London landscape. ${ }^{27}$ Such arguments had already been aired and dismissed after the Second World War when the decision was controversially made to construct a large power station in this location. As two members of Southwark Council speculated in I947:

The erection of such a building is bound ... to lose possibly for ever, the opportunity now presented of making the area reconcilable with the magnificence of the opposite bank and worthy of its associations with the ever-lasting memories of Shakespeare, Dickens, Wren, and others, and of its position on the most famous waterfront and in the heart of the greatest city in the world. ${ }^{28}$

Despite the proximity to St Paul's Cathedral, the power station's 99 m chimney meant that a precedent had already been set for tall, modern buildings in this area.

Instead, battles lines tended to coalesce around two axes. First, following Ken Livingstone's new pro-tall building agenda, arguments emphasised the proposed tower's role in revitalising a downgraded area, boosting residential density and providing affordable housing. This was a position that London Town frequently highlighted, particularly when the development was held up by legal appeals. In contrast, opponents of the tower emphasised the greater importance of the Tate's role as a national institution and public space. Yet this overlooked much of the original rationale behind the public funding of Tate Modern. By choosing a derelict power station in Bankside, the Tate deliberately sought to strengthen their application for $£_{50}$ million from the National Lottery by being able to emphasise their new gallery's role in processes of inner-city regeneration. The Hopton Street tower is an example of the new property investment that it was hoped the Tate would encourage. As Jeremy Fraser, the leader of Southwark Council between I993 and I997 and instrumental in attracting the Tate to the area, explains 'whilst some people might be upset at it, I feel it [the tower] is perhaps a monument to what the area's become'. ${ }^{29}$ Unlike other large new schemes near the Tate, such as Land Securities' I-2-3 Bankside project, it is the close proximity of the Hopton Street site to the Tate's western entrance that has proved contentious.

The second battleground marshalled has been in relation to architectural design. As with other controversial tall buildings in London over the last decade, a focus on architectural quality was used by proponents of the tower as a way of attempting to defuse antagonism towards it. ${ }^{30}$ During the planning inquiry, for example, the architect Anthony Blee, expert witness for the developers, awkwardly compared the proposed tower with the Campanile of San Marco in Venice, with the inspector concluding that the tower might 'act as a catalyst for improved design quality for future buildings in the area. ${ }^{3 \mathrm{I}}$ In contrast, opponents insisted the tower would damage the visual coherence of the area and overshadow Piers Gough's Bankside Lofts and the iconic conversion of Giles Gilbert Scott's power station. Nonetheless, both sides emphasised the 'outstanding design' of their respective buildings, and - consistent with a reassertion of London's 'global city' status over the last decade - their place within wider European and international urban imaginaries. This similarity in approach has meant that design arguments largely proved inconclusive.

This shared emphasis on architectural design and recourse to discourses of inner-city regeneration confirms how both sides, although squabbling over the tower, 
have been implicated in the promotion of a similar agenda of economic growth. Livingstone and Serota have both eagerly courted the City of London and property developers. Livingstone has cast off his anti-business inclinations from the Greater London Council (GLC) era of the I980s, and used the City's resources as a pragmatic solution to his comparably restricted fiscal and administrative power. ${ }^{32}$ Serota has also increasingly looked to the City of London, situated directly across the Thames from Tate Modern, for support and sponsorship. In this he has recognised how the new internationally orientated cultural landscape created by the Tate in Bankside has bolstered the City's attempts to consolidate its position as Europe's - and indeed London's - leading financial centre. Despite their disagreements with London Town, the Tate has also cultivated relationships with property companies. The 2007 Global Cities exhibition, for instance, held in Tate Modern's Turbine Hall was sponsored by Land Securities, the office development specialist Derwent and the global real estate service provider Savills.

Both Livingstone and Serota have similarly been keen proponents of intensifying and extending regeneration processes on the traditionally marginalised south side of the Thames. Building on Tate Modern's existing impact as 'the major driver of regeneration at Bankside', a southern extension to the gallery was proposed in July 2006 within a new 7I $\mathrm{m}$ high ziggurat-shaped glazed structure $-8 \mathrm{~m}$ taller than the revised Hopton Street tower. ${ }^{33}$ At the launch event, Nicolas Serota stated he hoped the extension would 'help to regenerate the Bankside area and turn it into a cultural quarter'. Ken Livingstone, also at the event, concurred: 'I am delighted that the new development will enable the Tate to ... play a key role in the regeneration of the surrounding area' and announced a $£_{7}$ million grant from the London Development Agency. ${ }^{34}$ With proposals for the extension taking up open space and introducing a service yard close to the Hopton Street site, it seems the gallery's regeneration potential has superseded Serota's concerns over protecting the public realm around the existing building.

This similarity in agenda is a direct consequence of the recent political landscape in which Livingstone and Serota have operated. In contrast to the early I980s, when Livingstone's GLC successfully fought off the developers Greycoats and their Richard Rogers-devised plan for a string of blocks linked along the South Bank, Livingstone has been forced to embrace developers as a way of securing affordable housing provision - appointing Rogers as his special advisor on urban policy in June 2000. The Tate has likewise been compelled to highlight their role in processes of urban economic revitalisation in order to help win public funding. As Rowan Moore argues, the Tate has 'had to sell itself to the government as an agent of regeneration above all else; in other words as a benign business opportunity.' 35 Over the last 20 years, this business agenda has become hegemonic within urban policy-making in London, privileging commercial development over social provision, and emphasising the need to continually assert and protect London's 'global' financial competitiveness.

An important aspect to this regime has been efforts to neutralise dissent and critique as part of a general 'hollowing out' of democratic politics in London. Consistent with how London's mayoralty was conceived by New Labour as akin to a dynamic chief executive, Livingstone's original consultation with London Town over the Hopton Street site was held behind closed doors. Unlike local council planning meetings, not only the public but GLA members were barred from attending. 
The autonomy and input of the local elected representatives was again bypassed with the overturning by a national government-appointed planning inspector of the crossparty decision by borough councillors to block the tower. This decision in itself against the advice of the planning officer - is likely to have also been swayed by the political influence of the Tate. Its role in receiving major lottery funding and maximising the revenue yield of its riverside location has meant that it has been Serota and the Tate's unelected trustees, rather than Southwark Council, who have set much of the agenda for Bankside's regeneration.

With property-led development positioned politically as the only option for an area such as Bankside, it has been assumed that a site like the one at Hopton Street will be redeveloped as an upmarket residential tower. Even Coin Street Community Builders, situated just to the west of Bankside and long heralded as an explicitly socially focused example of property development, submitted proposals in May 2007 for a riverside tower of luxury apartments. This was justified as a means of financing a new swimming pool and creating 'a substantial increase in the residential population of the area to support the local economy'. ${ }^{36}$ Against this common focus on the provision of residential, commercial and retail space for high-income users - albeit with a contemporary dance centre, landscaped park, off-site affordable housing or similar thrown in for 'public' gain - there is a pressing need to imagine alternatives. Before being bought by London Town, 44-47 Hopton Street was not a 'dilapidated warehouse' or 'brownfield' site, as commonly assumed, but a fully operational paper wholesaler. Such stories of how employment has been lost or relocated in sectors not deemed suitably contingent with London's 'global city' status have largely been neglected in the hoopla surrounding the internationally celebrated revitalisation of areas such as Bankside. ${ }^{37}$ Similarly, architectural imaginations remain firmly yoked to middle-class consumption practices, visual ordering and piazza-style, closely regulated public space - albeit of 'high-quality' design. ${ }^{38}$ In the world of speculation, negotiation and imagination that spawns inner London's future built environment, there remains an urgent need to conceive different visions to the usual recourse to luxury housing and upmarket office and retail opportunities — whether at ground level or one hundred metres up.

\section{Acknowledgement}

Many thanks to Alex Veness, Jane Levi, Theresa Towle, Philip Gumuchdjian, Gary Douglas at Southwark Planning Department and two anonymous reviewers for their help and comments. With thanks also to support from an ESRC Postdoctoral Fellowship Award PTA-026-27-I577.

\section{Notes}

I See, for example, H. Wright, London High (2006); D. Long, Spectacular Vernacular (2006).

2 See M. Hajer, 'Rebuilding Ground Zero. The Politics of Performance', Planning Theory \& Practice, 6:4 (2005), 445-64. See also J. Jacobs, 'The Battle of Bank Junction: the Contested Iconography of
Capital', in S. Corbridge, R. Martin and N. Thrift (eds.), Money, Power and Space (I994), 356-82.

3 See, for example, D. Taylor, 'Whole Tower of Trouble in the Shadow of Tate Modern', Architects' Journal (8 Aug 2003), 22-3; and R. Moore, 'A Towering Shame', Evening Standard (20 May 2003), 39. 
4 The 'cheese grater' refers to a 225 metre, Richard Rogers designed building at I22 Leadenhall Street, scheduled to be built by $201 \mathrm{I}$. The 'walkie talkie' refers to a I60 metre, Rafael Vinoly designed building at 20 Fenchurch Street, also due to be completed by $201 \mathrm{I}$.

5 Much to the chagrin of the Tate, who successfully stopped the developer using this name.

6 L. Reilly and G. Marshall, The Story of Bankside: from the River Thames to St George's Circus (200I).

7 M. Davidson, 'New Build Gentrification: London's Riverside Renaissance' (Unpublished Ph.D. thesis, Kings' College London, 2006).

8 D. McNeill, 'The Mayor and the World City Skyline: London's Tall Buildings Debate', International Planning Studies, 7:4 (2002), 325-34.

9 'Interim Strategic Planning Guidance on Tall Buildings, Strategic Views and the Skyline in London'. Mayor of London, Oct 200 I.

ro M. Bar-Hillel, 'Developers Halt Plans for Glass Tower at Tate Modern', The Evening Standard (I 5 Jan 2002), II.

II Particularly the knocking down of its chimney which not only echoed the adjacent chimney of the former power station, but was an architectural detail which strengthened the case for listing the building.

I2 Southwark Planning Department (44-47 Hopton Street file, Part ${ }_{3} \mathrm{~B}$ ).

${ }^{13}$ See A. Harris, 'Branding Urban Space: the Creation of Art Districts in Contemporary London and Mumbai' (Unpublished Ph.D. thesis, University College London, 2006).

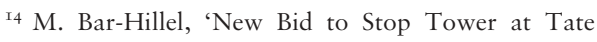
Modern', Evening Standard (I7 Dec 200I), 20.

${ }^{15}$ J. Bale, 'Prince Cuts Down Tall Buildings', The Times (I2 Dec 200I).

I6 'Bankside Tower Goes to the Planners', The Planner (I7 Aug 200I).

${ }^{17}$ Southwark Planning Department, O2-AP-IO45. Indeed, the one letter of support strikes a notably sarcastic tone: 'Fantastic! Can't wait for it to start, really looking forward to this development as it is one of the few "blots" left on the SEI landscape.'
${ }^{18}$ Appeal Ref: APP/A5850/A/O2/IIO2404 (9 Jun 2003).

${ }^{19}$ D. Arnold, 'Tower Hits Tate Wall', Building Design (26 Sep 2003), I.

${ }^{20}$ As one member of BROAD stated in an interview, 'some of our members had considerable funds at their disposal'.

${ }^{2 I}$ S. Rowe, 'Residents Lose Appeal Court Battle to Block Tate Tower', EGi News (I2 Jul 2004).

${ }^{22}$ M. Bar-Hillel, 'Bankside Tower Block Battle Heads to Europe', Evening Standard (I7 Dec 2004), 8.

${ }_{23}$ Two members of BROAD bought shares in London Town plc, received the annual report and attended the AGM.

${ }^{24}$ Southwark Planning Department 06-AP-I48I.

25 Ibid.

${ }^{26}$ GLA Planning Report PDU/IO39(insert case number)/or (Oct 2006). See also, Letter from Serota to Cllr James Gurling, I3 Nov 2006.

27 Although BROAD did emphasise the loss of Bankside's Victorian heritage with the demolition of the chimney at 44-47 Hopton Street.

${ }^{28}$ Letter to The Times (26 Apr 1947).

29 Interview, Feb 2004.

$3^{30}$ I. Charney, 'The Politics of Design: Architecture, Tall Buildings and the Skyline of Central London', Area, 39:2 (2007), I985-2005.

${ }^{31}$ Moore (2003).

${ }^{32}$ D. McNeill, 'Livingstone's London: Left Politics and the World City', Regional Studies, 36:I (2002), 75-91.

33 Southwark Planning Department 06-AP-I9I3.

${ }^{34}$ R. Moore, 'A Glass Pyramid for Tate Modern', Evening Standard (25 Jul 2006), 38.

35 Ibid.

${ }^{36}$ http://www.coinstreet.org/DoonStreetMay2007exhibitionboardshires.pdf (accessed I5 Nov 2007).

37 See also W. Curran, 'From the Frying Pan to the Oven: Gentrification and the Experience of Industrial Displacement in Williamsburg, Brooklyn', Urban Studies, 44:8 (2007), I427-40.

$3^{8}$ I. Borden, 'What is Radical Architecture?' in M. Malcolm and T. Hall (eds.), Urban Futures (2003), III-2I; A. Amin, D. Massey and N. Thrift, Cities for the Many not the Few (2000).

\section{Notes on Contributor}

Dr Andrew Harris is a Research Fellow at the Department of Geography, University College London. He is currently writing a book critically examining and comparing the role of art and artists in recent processes of urban transformation in London and Mumbai. 